\title{
Efektivitas Penggunaan Media Sains Flipbook Berbasis Kontekstual untuk Meningkatkan Kemampuan Berfikir Kritis Siswa
}

\author{
Tika Aprilia* \\ Pendidikan Sekolah Dasar, Fakultas Ilmu Pendidikan, Universitas Negeri Yogyakarta \\ J1. Colombo No. 1 Yogyakarta \\ *Corresponding Author. e-mail: tika.aprilia@uny.ac.id
}

\begin{abstract}
Abstrak
Penelitian ini bertujuan untuk mengetahui keefektifan media sains flipbook berbasis kontekstual dalam meningkatkan kemampuan berpikir kritis siswa kelas V Sekolah Dasar. Jenis penelitian yang digunakan adalah penelitian kuantitatif dengan metode eksperimen. Desain eksperimen yang digunakan yaitu desain true-experimental berupa post-test only control group design. Sampel penelitian ini terdiri dari kelas V-1 SDN Mangkubumen Lor sebanyak 26 siswa sebagai kelas eksperimen, sedangkan kelas kontrolnya yaitu kelas VA SDN Cemara Dua sebanyak 26 siswa. Pemilihan sampel sekolah dasar tersebut dilakukan secara purposive sampling. Instrumen yang digunakan berupa butir soal tes untuk mengetahui kemampuan berpikir kritis siswa yang disusun berdasarkan integrasi antara indikator kemampuan berpikir kritis dengan domain kemampuan kognitif dalam taksonomi Bloom yang telah diuji validitas dan reliabilitas butir soal. Hasil penelitian ini menunjukkan bahwa nilai rata-rata hasil belajar siswa yang menggunakan media sains flipbook berbasis kontekstual $(88,12)$ lebih tinggi dibandingkan dengan nilai rata-rata hasil belajar siswa yang menggunakan buku paket IPA pada umumnya $(75,31)$. Hasil uji independen sample t-test diperoleh signifikansi $0,000<0,05$ artinya $\mathrm{H}_{0}$ ditolak menunjukkan bahwa ada perbedaan nilai kemampuan berpikir kritis siswa pada kelas eksperimen yang menggunakan media sains flipbook berbasis kontekstual dengan kelas kontrol yang menggunakan media buku cetak atau paket IPA. Skor nilai kemampuan berpikir kritis siswa yang menggunakan media sains flipbook berbasis kontekstual lebih tinggi daripada skor nilai kemampuan berpikir kritis siswa yang hanya menggunakan media buku paket IPA. Namun dalam penggunaan media sains flipbook berbasis kontekstual ini sangat membutuhkan sarana prasarana atau fasilitas sekolah yang memadai.
\end{abstract}

Kata Kunci: media sains flipbook, kontekstual, berpikir kritis, siswa sekolah dasar

\section{The Effectiveness of the Use of Flipbook Science Media Based on Contextual to Improve Critical Thinking Ability of Students}

\begin{abstract}
This study aims at determining the effect of flipbook science media base on contextual to enhance critical thinking skills for students of class $V$ in elementary schools. This research is quantitative research by using the experimental method. The experiment design used is a true-experiment design in the form of a posttest-only control group design. The sample of this study is a V-1 class of Mangkubumen Lor state elementary school as many as 26 students as the experiment class, while the control class was VA class of the Cemara Dua state elementary school with as many as 26 students. The selection of the three elementary school samples was done by purposive sampling. The instrument used is a form of test items at determining students' critical thinking skills compiled based on the integration between indicators of critical thinking skills with the domain of cognitive abilities in Bloom's taxonomy that had been tested for validity and reliability of the items. The results of this study indicate that the average value of students learning outcome using flipbook science media base on contextual (88.12) is higher than the average value of students learning outcome using natural science textbooks (75.31). The results of the independent sample t-test obtained a significance of $0.000<0.05$, meaning that $\mathrm{H}_{0}$ is rejected, indicating that there is a value of students' critical thinking skills in the experimental class using flipbook science media base on contextual with the control class using science textbooks media or science packages. Scores the value of the critical thinking ability of students using flipbook science media base on contextual is higher than the value of the critical thinking ability of students only using the science textbooks media. However, the use of
\end{abstract}


flipbook science media base on contextual really requires adequate school infrastructure or facilities. Keywords: flipbook science media, contextual critical thinking, elementary school students

How to Cite: Aprilia, T. (2021). Efektivitas penggunaan media sains flipbook berbasis kontekstual untuk meningkatkan kemampuan berfikir kritis siswa. Jurnal Penelitian Ilmu Pendidikan, 14(1), 10-21. doi: https://doi.org/10.21831/jpipfip.v14i1.32059.

Received 29-05-2020; Received in revised from 29-06-2020; Accepted 16-02-2021

This is an open-access article under the CC-BY-SA license.

\section{PENDAHULUAN}

Pendidikan di Indonesia telah memasuki pembelajaran abad 21. Bahkan kompetensi pembelajaran abad 21 ini sudah diadaptasi dalam sistem pendidikan di Indonesia melalui Kurikulum 2013 (Andrian \& Rusman, 2019). Empat kompetensi pembelajaran abad 21 yang biasa disingkat dengan $4 \mathrm{C}$ tersebut, meliputi critical thinking (berpikir kritis), collaboration (kemampuan bekerja sama dengan baik), communication (berkomunikasi) dan creativity (kreativitas). Salah satu kompetensi yang perlu ditanamkan pada diri siswa sejak dini yaitu critical thinking atau kemampuan berpikir kritis. Kemampuan berfikir kritis merupakan kemampuan untuk mengidentifikasikan dan merumuskan suatu problem, yang mencakup menentukan intinya, menemukan kesamaan dan perbedaan, menggali informasi serta data yang relevan (Winkel, 2007). Kemampuan berpikir kritis meliputi pengetahuan untuk membuat seangkaian pertanyaan kritis yang saling berkaitan serta kemampuan dan kemauan untuk bertanya dan menjawab pertanyaan-pertanyaan tersebut pada saat yang tepat (Brownie \& Keeley, 2015). Oleh karena itu kemampuan berpikir kritis berhubungan juga dengan kemampuan berpikir dan bertanya seseorang. Hal ini bisa dilakukan ketika proses pembelajaran sains.

Pembelajaran sains menuntut siswa sekolah dasar untuk memiliki kemampuan menggunakan alat tertentu, kemampuan mengamati benda dan lingkungan sekitarnya, kemampuan mendengarkan, kemampuan berkomunikasi secara efektif, menanggapi, dan memecahkan masalah secara efektif (Samatowa, 2011). Oleh sebab itu, perlu ditanamkan kemampuan berpikir kritis pada diri siswa sejak dini melalui pembelajaran sains tersebut. Selain itu, dalam pembelajaran sains diperlukan dalam kehidupan sehari-hari siswa untuk memenuhi kebutuhan manusia melalui pemecahan masalahmasalah yang dapat diidentifikasikan. Penerapan IPA ini perlu dilakukan secara bijaksana agar tidak berdampak buruk terhadap lingkungan, sehingga materi yang pada pembelajaran sains harus berbasis kontekstual sesuai dengan kehidupan siswa. Dimana pendekatan kontekstual merupakan konsep belajar yang membantu guru mengkaitkan antara materi yang diajarkan dengan situasi dunia nyata siswa dan mendorong siswa membuat hubungan antara pengetahuan yang dimilikinya dengan penerapannya dalam kehidupan mereka sebagai anggota keluarga dan masyarakat (Aqib, 2014), sehingga dengan konsep ini pembelajaran akan lebih bermakna bagi siswa. Proses pembelajaran berlangsung alamiah dalam bentuk kegiatan siswa bekerja dan mengalami, bukan mentransfer pengetahuan dari guru ke siswa.

Hasil survei PISA tahun 2015 Indonesia berada di urutan ke-62, alias peringkat kesembilan dari bawah. Dalam kategori Sains, Indonesia memperoleh skor 403, jauh di bawah rata-rata skor OECD 489. Sedangkan dalam Membaca, Indonesia berada di peringkat ke-9 dari bawah dengan skor 397 dengan rata-rata OECD 487. Sementara skor terendah yang diperoleh Indonesia ada pada kategori Metematika, yaitu sebesar 386 dengan rata-rata OECD 489 (OECD, 2016). Hal ini menunjukkan perlu adanya perbaikan dan peningkatan terhadap kualitas pembelajaran sains yang selama ini dilakukan di sekolah dasar.

Permasalahan tersebut juga terjadi pada ketiga sekolah dasar negeri yang menjadi sampel dalam penelitian ini. Hasil observasi tanggal 5-16 September 2017 pada saat proses pembelajaran IPA dan wawancara dengan guru kelas $\mathrm{V}$ di ketiga sekolah dasar menunjukkan bahwa kemampuan berpikir siswa di SDN Cemara Dua, SDN Mangkubumen Kidul No. 16, dan SDN Mangkubumen Lor No. 15 masih rendah, hanya 2-4 siswa (10\% dari jumlah siswa pada setiap kelasnya) yang mampu 
mengungkapkan pendapatnnya, bertanya, ataupun menyimpulkan dan memecahkan suatu permasalahan yang diajukan oleh guru. Hal ini menunjukkan kemampuan berpikir kritis siswa masih rendah pada mata pelajaran IPA. Kemampuan berpikir kritis siswa yang rendah tersebut terjadi dikarenakan beberapa faktor, sehingga perlu dilakukan analisis.

Hasil wawancara dengan siswa kelas V di SDN Cemara Dua, SDN Mangkubumen Kidul No. 16, dan SDN Mangkubumen Lor No. 15 pada tanggal 15-20 September 2017, siswa beranggapan bahwa buku cetak yang digunakan sekarang kurang menarik, kurang berwarna, dan terlalu banyak teksnya, serta kurang praktis karena berat dalam membawanya. Sedangkan, BSE yang digunakan di sekolah-sekolah sekarang ini juga masih memiliki kelemahan-kelemahan yang patut disempurnakan. BSE yang dikemas dalam bentuk e-book tersebut belum memiliki nilai lebih, masih seperti buku cetak lainnya yang banyak beredar. Hal ini mengindikasikan media pembelajaranlah yang menjadi penyebab dari rendahnya kemampuan berpikir kritis siswa dalam pembelajaran IPA. Oleh sebab itu, diperlukan adanya alternatif media yang dapat meningkatkan kemampuan berpikir kritis siswa seperti media sains flipbook. Media pembelajaran sains flipbook berbasis kontekstual ini merupakan pengembangan dari $e$-book sebagai salah satu alternatif untuk memudahkan pembelajaran IPA, yang diharapkan dapat meningkatkan kemampuan berpikir kritis siswa, khususnya pada materi Gaya dan Pesawat Sederhana kelas V tingkat SD dan sederajat. Flipbook merupakan media pembelajaran yang menyajikan informasi dengan menampilkan rangkaian materi dalam bentuk buku elektronik digital yang dapat dibuka-buka (flip) menyerupai buku aslinya (Parlin, Iswanto \& Budi, 2015).

Keunggulan flipbook yang digunakan dalam penelitian ini yaitu dapat menyajikan teks, gambar, animasi, dan video yang dilengkapi dengan alat bantu (tool) dan koneksi (link), sehingga siswa dapat melakukan navigasi, interaksi dan komunikasi. Oleh sebab itu, tujuan penelitian ini adalah untuk mengetahui keefektifan media sains flipbook berbasis kontekstual dalam meningkatkan kemampuan berpikir kritis siswa kelas V Sekolah Dasar.

\section{METODE}

Penelitian ini merupakan penelitian eksperimen yang bertujuan untuk melihat keefektifan media sains flipbook berbasis kontekstual dalam meningkatkan kemampuan critical thinking siswa kelas V sekolah dasar. Pengujian efektivitas model atau produk merupakan tahap pengujian keefektifan dari produk yang dihasilkan dalam penelitian dibandingkan dengan pembelajaran biasa yang digunakan di sekolah (Sukmadinata, 2012). Dalam pelaksanaanya digunakan dua kelompok sampel, yaitu kelompok eksperimen dan kelompok kontrol. Adapun kelas eksperimen yaitu kelas yang menggunakan media sains flipbook berbasis kontekstual dalam pembelajaran. Sedangkan sebagai pembanding atau kelas kontrol adalah kelas yang tidak menggunakan media sains flipbook berbasis kontekstual dalam pembelajaran (hanya menggunakan buku paket/cetak IPA).

Desain eksperimen yang digunakan dalam penelitian ini yaitu menggunakan desain trueexperimental berupa Post-test Only Control Group Design. Desain eksperimen ini menjelaskan bahwa terdapat dua kelompok yang masing-masing dipilih secara random. Grup pertama diberi perlakuan (X) dan grup yang lain tidak diberi perlakukan (Suryabrata, 2014). Dalam desain ini terdapat dua kelompok, kelompok pertama diberi perlakuan dengan menggunakan media sains flipbook berbasis kontekstual pada mata pelajaran IPA yang selanjutnya disebut sebagai kelas eksperimen, sedangkan kelompok lainnya tidak menggunakan media sains flipbook berbasis kontekstual dalam pembelajaran (hanya menggunakan buku cetak IPA) yang selanjutnya disebut sebagai kelas kontrol dan kedua kelompok diberikan soal post-test tanpa adanya pre-test karena nilai pre-test sudah di dapat dari hasil nilai awal UAS IPA semester 1. Sebelum melakukan uji efektifitas, nilai awal kelas ekperimen dengan kelas kontrol dilakukan uji kesetaraan dengan menggunakan uji-t. Uji efektifitas ini dilakukan untuk membandingkan 2 hal yaitu 1) nilai pre-test dan post-test kelas ekperimen dan 2) nilai post-test antara kelas ekperimen dengan kelas kontrol.

Penelitian ini dilaksanakan di SDN Cemara Dua No. 13 Surakarta, SDN Mangkubumen Kidul No. 16 Surakarta, dan SDN Mangkubumen Lor No. 15 Surakarta. Pemilihan ketiga sampel sekolah dasar tersebut dilakukan secara purposive sampling berdasarkan kurikulum yang digunakan, akreditasi sekolah, fasilitas sekolah terutama untuk sekolah yang memiliki laboratorium komputer atau minimal terdapat LCD dan sound system pada setiap kelas dan prestasi sekolah. Subjek uji 
efektivitas penelitian ini yaitu kelas V-1 SD Negeri Mangkubumen Lor sebanyak 26 siswa sebagai kelas eksperimen, sedangkan kelas kontrolnya yaitu kelas VA SD Negeri Cemara Dua sebanyak 26 siswa.

Instrumen yang digunakan dalam pengujian efektivitas model atau produk untuk mengumpulkan data yaitu butir soal tes untuk mengetahui kemampuan berpikir kritis siswa yang disusun berdasarkan integrasi antara indikator kemampuan berpikir kritis dengan domain kemampuan kognitif dalam taksonomi Bloom. Butir soal ini sebelum digunakan untuk uji efektivitas, dilakukan uji validitas dan reliabilitas butir soal. Butir soal sebanyak 34 soal pilihan ganda diujicobakan pada 29 siswa kelas V-2 SDN Mangkubumen Lor No. 15. Berdasarkan hasil uji validitas dan reliabilitas dengan program ITEMAN diperoleh bahwa dari 34 butir soal pilihan ganda yang diujikan, terdapat 4 soal yang tidak valid dan 30 soal valid. Rincian soal yang tidak valid yaitu 1 soal pada KD 5.1 (Gaya) dan 3 soal KD 5.2 (Pesawat sederhana), sehingga dapat disimpulkan jumlah soal pilihan ganda yang valid yaitu 30 soal pilihan ganda (KD 5.1 dan KD 5.2). Sedangkan koefisien reliabilitas Alpha adalah $0,746>0,7$ yang berarti reliabilitas soal baik. Kemudian, butir soal berupa uraian juga dilakukan uji validitas melalui ahli dan praktisi. Dalam penelitian ini expert yang digunakan sebanyak 4 expert, yang terdiri dari 1 Dosen IPA SD dan 3 Guru kelas V. Hasil validitas tersebut menunjukkan bahwa 10 soal uraian tersebut sudah sesuai dengan indikator pembelajaran dan indikator kemampuan berpikir kritis, sehingga layak atau valid untuk digunakan. Sedangkan untuk reliabilitas butir soal uraian diuji dengan menggunakan reliabilitas Alpha Cronbach memperoleh nilai alpha 0,804 > 0,7 yang berarti butir soal uraian dinyatakan reliabel dan dapat digunakan.

Tes ini hanya berupa post-test yang diberikan kepada siswa baik di kelas ekperimen (menggunakan e-book yaitu media sains flipbook berbasis kontesktual) maupun kelas kontrol setelah proses pembelajaran selesai. Hasil tes tersebut digunakan untuk mengetahui efektivitas media yang dikembangkan. Butir tes yang diujikan ke 26 siswa kelas V-1 SDN Mangkubumen Lor berjumlah 40 butir soal yang terdiri dari 30 soal pilihan ganda dan 10 soal uraian untuk dua KD yang diajarkan.

Teknik analisis data menggunakan uji-t. Perhitungan uji-t dilakukan dengan bantuan program SPSS yaitu independent sample $t$-test. Sebelum dilakukan uji-t terlebih dahulu dilakukan uji prasyarat analisis. Uji normalitas untuk mengetahui normalitas kedua variansi secara manual menggunakan uji Liliefors. Dalam penelitian ini, analisis data uji normalitas dilakukan dengan uji Shapiro-Wilk menggunakan program SPSS 19.0, dengan taraf signifikansi 0,05. Jika $p$-value > 0,05 maka sebaran data normal, sedangkan jika $p$-value $<0,05$ maka sebaran data tidak normal. Setelah didapatkan normalitas kedua variansi, maka uji prasyarat analisis kedua adalah uji homogenitas. Homogenitas kedua variansi secara manual dapat menggunakan uji Bartlet. Dalam penelitian ini, analisis data uji homogenitas dilakukan dengan One-Way Anova program SPSS 19.0, dengan taraf signifikansi $(\alpha)$ 0,05 . Jika p-value >0,05 maka kedua kelompok homogen atau berasal dari varian yang sama, sedangkan jika p-value < 0,05 maka kedua kelompok tidak homogen atau tidak berasal dari varian yang sama. Kemudian untuk mengetahui kesetaraan prestasi belajar siswa atau kemampuan awal yang dimiliki siswa antara kelas eksperimen dengan kelas kontrol dilakukan uji kesetaraan sebelum dilakukan uji efektivitas. Pada uji kesetaraan ini menggunakan uji Independent Sample T-Test dengan bantuan program SPSS. Data yang diujikan adalah nilai UAS IPA semester 1 pada kelas eksperimen dengan nilai UAS IPA semester 1 pada kelas kontrol.

Butir soal yang akan digunakan untuk mengukur kemampuan berpikir kritis siswa dalam uji efektifitas harus diukur valid dan reliabel tidaknya butir soal tersebut. Uji validitas dan reliabilitas butir soal dalam penelitian ini dilakukan dengan bantuan program ITEMAN. Subyek uji validitas butir soal dilakukan di SDN Mangkubumen Lor No. 15 pada kelas V-2 dengan jumlah responden sebanyak 29 siswa dan jumlah soal sebanyak 34 soal pilihan ganda. Sedangkan untuk soal uraian menggunakan validitas ahli dan praktisi yang disesuaikan dengan indikator pembelajaran dan indikator kemampuan berpikir kritis siswa.

\section{HASIL DAN PEMBAHASAN}

Hasil

Media sains flipbook berbasis kontekstual diimplementasikan dalam proses pembelajaran IPA. Kelompok siswa yang diberikan perlakukan dengan menggunakan media sains flipbook adalah 
kelas ekperimen (26 siswa kelas V-1 SDN Mangkubumen Kidul No. 16). Sedangkan kelompok siswa yang tidak diberikan perlakukan menggunakan media sains flipbook adalah kelas kontrol (26 siswa kelas VA SDN Cemara Dua).

\section{Uji Kesetaraan}

Uji kesetaraan dilakukan untuk mengetahui kesetaraan prestasi belajar siswa atau kemampuan yang dimiliki antara kelas eksperimen dengan kelas kontrol sebelum dilakukan uji efektivitas. Pada uji kesetaraan ini menggunakan uji Independent Sample T Test. Data yang diujikan adalah nilai UAS semester 1 pada kelas eksperimen dengan nilai UAS semester 1 pada kelas kontrol. Hasil perhitungan uji normalitas dan uji homogenitas pada uji kesetaraan dengan menggunakan program SPSS adalah sebagai berikut.

\begin{tabular}{|c|c|c|c|c|}
\hline & \multirow{2}{*}{ Kelompok } & \multicolumn{3}{|c|}{$\begin{array}{l}\text { Shapiro-Wilk } \\
\end{array}$} \\
\hline & & Statistic & df & Sig. \\
\hline \multirow[t]{2}{*}{ Nilai } & Eksperimen & .923 & 26 & .053 \\
\hline & Kontrol & .968 & 26 & .578 \\
\hline
\end{tabular}

Tabel di atas menunjukkan data perhitungan uji normalitas bahwa nilai sig $0,053>0,05$ untuk nilai awal kelas eksperimen dan nilai sig 0,578>0,05 untuk nilai awal kelas kontrol, maka dapat dikatakan nilai awal kelas eksperimen dan kelas kontrol adalah data yang berdistribusi normal.

\begin{tabular}{|c|c|c|c|}
\hline Levene Statistic & df1 & $\mathrm{df} 2$ & Sig. \\
\hline .627 & 1 & 50 & .432 \\
\hline
\end{tabular}

Tabel 2 menunjukkan data perhitungan uji homogenitas, diperoleh nilai sig 0,432>0,05 sehingga data nilai awal kelas eksperimen dan kelas kontrol dapat dikatakan homogen.

Data di atas dikatakan berdistribusi normal dan homogen, maka data nilai awal kelas eksperimen dan kelas kontrol selanjutnya dilakukan perhitungan uji hipotesis (uji-t) untuk mengetahui kemampuan awal yang dimiliki kelas kontrol dengan kelas awal sama satau tidak. Hasil uji-t pada uji kesetaraan dengan menggunakan Independent Sample T Test adalah sebagai berikut:

Tabel 3. Hasil Uji Independent Sample T Test pada Uji Kesetaraan

\begin{tabular}{llcccc}
\multicolumn{5}{c}{ Group Statistics } \\
& Kelompok & $\mathrm{N}$ & Mean & $\begin{array}{c}\text { Std. } \\
\text { Deviation }\end{array}$ & $\begin{array}{c}\text { Std. } \\
\text { Error } \\
\text { Mean }\end{array}$ \\
\hline Nilai & Eksperimen & 26 & 75.92 & 3.509 & .688 \\
& Kontrol & 26 & 75.08 & 4.326 & .848 \\
\hline
\end{tabular}

Sumber: Data dari SPSS 19

\begin{tabular}{|c|c|c|c|c|c|c|c|c|c|c|}
\hline \multicolumn{11}{|c|}{ Independent Samples Test } \\
\hline & & $\begin{array}{r}\text { Lev } \\
\text { Tes } \\
\text { Equa } \\
\text { Vari } \\
\end{array}$ & $\begin{array}{l}\text { ne's } \\
\text { for } \\
\text { ity of } \\
\text { nces }\end{array}$ & & \multicolumn{6}{|c|}{ t-test for Equality of Means } \\
\hline & & \multirow[t]{2}{*}{$\mathrm{F}$} & \multirow[t]{2}{*}{ Sig. } & \multirow[t]{2}{*}{$\mathrm{t}$} & \multirow[t]{2}{*}{ df } & \multirow{2}{*}{$\begin{array}{c}\text { Sig. } \\
(2- \\
\text { taile } \\
\text { d) }\end{array}$} & \multirow{2}{*}{$\begin{array}{c}\text { Mea } \\
\mathrm{n} \\
\text { Diffe } \\
\text { rence }\end{array}$} & \multirow{2}{*}{$\begin{array}{c}\text { Std. } \\
\text { Error } \\
\text { Diffe } \\
\text { rence }\end{array}$} & \multicolumn{2}{|c|}{$\begin{array}{c}95 \% \text { Confidence } \\
\text { Interval of the } \\
\text { Difference } \\
\end{array}$} \\
\hline & & & & & & & & & Lower & Upper \\
\hline Nilai & $\begin{array}{l}\text { Equal } \\
\text { varian } \\
\text { ces } \\
\text { assum } \\
\text { ed }\end{array}$ & .627 & .432 & $\begin{array}{l}.7 \\
75\end{array}$ & 50 & .442 & .846 & $\begin{array}{c}1.09 \\
2\end{array}$ & -1.348 & 3.040 \\
\hline
\end{tabular}


Jurnal Penelitian Ilmu Pendidikan, 14 (1), 2021 - 15

Aprilia

\begin{tabular}{|c|c|c|c|c|c|c|c|c|c|c|}
\hline \multicolumn{11}{|c|}{ Independent Samples Test } \\
\hline & & $\begin{array}{c}\text { Lev } \\
\text { Tes } \\
\text { Equa } \\
\text { Vari }\end{array}$ & $\begin{array}{l}\text { ne's } \\
\text { for } \\
\text { ty of } \\
\text { nces }\end{array}$ & \multicolumn{7}{|c|}{ t-test for Equality of Means } \\
\hline & & \multirow[t]{2}{*}{$\mathrm{F}$} & \multirow[t]{2}{*}{ Sig. } & \multirow[t]{2}{*}{$\mathrm{t}$} & \multirow[t]{2}{*}{$\mathrm{df}$} & \multirow{2}{*}{$\begin{array}{c}\text { Sig. } \\
(2- \\
\text { taile } \\
\text { d) }\end{array}$} & \multirow{2}{*}{$\begin{array}{c}\text { Mea } \\
n \\
\text { Diffe } \\
\text { rence }\end{array}$} & \multirow{2}{*}{$\begin{array}{c}\text { Std. } \\
\text { Error } \\
\text { Diffe } \\
\text { rence }\end{array}$} & \multicolumn{2}{|c|}{$\begin{array}{l}95 \% \text { Confidence } \\
\text { Interval of the } \\
\text { Difference }\end{array}$} \\
\hline & & & & & & & & & Lower & Upper \\
\hline \multirow[t]{2}{*}{ Nilai } & $\begin{array}{l}\text { Equal } \\
\text { varian } \\
\text { ces } \\
\text { assum } \\
\text { ed }\end{array}$ & .627 & .432 & $\begin{array}{l}.7 \\
75\end{array}$ & 50 & .442 & .846 & $\begin{array}{c}1.09 \\
2\end{array}$ & -1.348 & 3.040 \\
\hline & $\begin{array}{l}\text { Equal } \\
\text { varian } \\
\text { ces } \\
\text { not } \\
\text { assum } \\
\text { ed }\end{array}$ & & & $\begin{array}{l}.7 \\
75\end{array}$ & $\begin{array}{c}47.9 \\
60\end{array}$ & .442 & .846 & $\begin{array}{c}1.09 \\
2\end{array}$ & -1.350 & 3.043 \\
\hline
\end{tabular}

Berdasarkan tabel 3 data uji Independent Sample $T$ Test menunjukkan bahwa nilai propabilitas atau sig. (2-tailed) yaitu 0,445 > 0,05 yang artinya $\mathrm{H}_{0}$ diterima atau tidak ada perbedaan nilai awal siswa antara kelas eksperimen dengan kelas kontrol. Adapun rata-rata nilai awal pada kelas eksperimen yaitu 75,92 dan rata-rata nilai awal pada kelas kontrol yaitu 75,08. Selisih perbedaan rataratanya 0,846 dengan perbedaan kisaran antara $-1,348$ sampai 3,040. Selain itu, Dilihat pada kriteria penilaian koefiensi $t_{\text {hit }}$ lebih kecil dari nilai koefiensi $t_{\text {tab }}$ maka $\mathrm{H}_{0}$ diterima. Adapun hasil yang diperoleh adalah $t_{\text {hit }}=0,775$ dikonsultasikan pada $t_{\text {tab }}=2,009$ (taraf signifikansi $5 \%$ dan $\mathrm{df}=50$ ), sehingga dapat dikatakan bahwa $t_{\text {hit }}>t_{\text {tab }}$ atau $0,775>2,009$ yang artinya tidak ada perbedaan nilai awal siswa antara kelas eksperimen dengan kelas kontrol. Dengan demikian dapat disimpulkan kemampuan awal siswa kelas eksperimen sama dengan kemampuan awal siswa kelas kontrol, sehingga kedua kelas tersebut dapat digunakan untuk uji efektivitas media sains flipbook berbasis kontekstual.

\section{Uji Efektivitas Perbandingan Nilai Pre-Test dan Post-Test Kelas Eksperimen}

Pada uji efektivitas perbandingan nilai pre-test dan post-test kelas eksperimen ini menggunakan uji Paired Sample T Test. Data yang diujikan adalah nilai pre-test pada kelas eksperimen dengan nilai post-test pada kelas eksperimen. Uji-t dapat dilakukan setelah data diketahui berdistribusi normal dan homogen, sehingga perlu dilakukan perhitungan uji normalitas dan uji homogenitas terlebih dahulu. Hasil perhitungan uji normalitas dan uji homogenitas dengan menggunakan program SPSS dapat dilihat pada tabel 4 dan 5 .

Tabel 4. Hasil Uji Normalitas pada Uji Efektivitas Pre-Test Post-Test Kelas Eksperimen

\begin{tabular}{ccccc}
\hline \multirow{2}{*}{ Kelompok } & \multicolumn{3}{c}{ Shapiro-Wilk } \\
\cline { 3 - 5 } Nilai & Statistic & $\mathrm{df}$ & Sig. \\
& Posttest & .976 & 26 & .776 \\
Sumber: Data dari SPSS & .923 & (Lilliefors Significance Correction)
\end{tabular}

Berdasarkan tabel 4. data perhitungan uji normalitas di atas menunjukkan bahwa nilai sig $0,776>0,05$ untuk nilai postest kelas eksperimen dan nilai sig 0,053>0,05 untuk nilai pre-test kelas eksperimen, maka dapat dikatakan data nilai pre-test dan post-test pada kelas eksperimen adalah data yang berdistribusi normal.

Tabel 5. Hasil Uji Homogenitas pada Uji Efektivitas Pre-Test Post-Test Kelas Eksperimen

\begin{tabular}{cccc}
\hline Levene Statistic & df1 & df2 & Sig. \\
\hline .435 & 1 & 50 & .513 \\
\hline
\end{tabular}

Sumber: Data dari SPSS 19

Tabel di atas menunjukkan data perhitungan uji homogenitas, diperoleh nilai sig 0,513>0,05 sehingga data pre-test dan post-test pada kelas eksperimen dapat dikatakan homogen. 
Berdasarkan keadaan data di atas yang dikatakan berdistribusi normal dan homogen, maka selanjutnya data nilai pre-test dan post-test pada kelas eksperimen akan dilakukan perhitungan uji hipotesis (uji-t). Hasil uji-t dengan menggunakan Paired Sample T Test dapat di lihat pada tabel 6.

Tabel 6. Hasil Uji Paired Sample T Test pada Uji Efektivitas Pre-Test Post-Test

Kelas Eksperimen

Paired Samples Statistics

\begin{tabular}{|c|c|c|c|c|c|c|c|c|c|}
\hline & & & \multicolumn{2}{|c|}{ Mean } & $\mathrm{N}$ & $\begin{array}{c}\text { Std. } \\
\text { Deviation }\end{array}$ & \multicolumn{3}{|c|}{$\begin{array}{l}\text { Std. Error } \\
\text { Mean }\end{array}$} \\
\hline \multirow[t]{2}{*}{ Pair 1} & \multicolumn{2}{|c|}{ Posttest } & \multicolumn{2}{|c|}{88.12} & 26 & 4.003 & \multicolumn{3}{|c|}{.785} \\
\hline & & retest & \multicolumn{2}{|c|}{75.92} & 26 & 3.509 & \multicolumn{3}{|c|}{.688} \\
\hline \multicolumn{10}{|c|}{ Paired Samples Test } \\
\hline & & \multicolumn{5}{|c|}{ Paired Differences } & \multirow{3}{*}{$\mathrm{t}$} & \multirow{3}{*}{$\mathrm{df}$} & \multirow{3}{*}{$\begin{array}{l}\text { Sig. } \\
(2- \\
\text { tailed } \\
\quad)\end{array}$} \\
\hline & & \multirow[t]{2}{*}{ Mean } & \multirow[t]{2}{*}{$\begin{array}{l}\text { Std. } \\
\text { Devia } \\
\text { tion }\end{array}$} & \multirow[t]{2}{*}{$\begin{array}{l}\text { Std. } \\
\text { Error } \\
\text { Mean }\end{array}$} & \multicolumn{2}{|c|}{$\begin{array}{l}95 \% \text { Confidence } \\
\text { Interval of the } \\
\text { Difference }\end{array}$} & & & \\
\hline & & & & & Lower & Upper & & & \\
\hline Pair 1 & $\begin{array}{l}\text { Postte } \\
\text { st - } \\
\text { Pretes } \\
\text { t }\end{array}$ & $\begin{array}{c}12.19 \\
2\end{array}$ & 4.128 & .810 & 10.525 & $\begin{array}{c}13.86 \\
0\end{array}$ & $\begin{array}{c}15.06 \\
0\end{array}$ & 25 & .000 \\
\hline
\end{tabular}

Berdasarkan data tabel di atas menunjukkan bahwa nilai propabilitas atau sig. (2-tailed) yaitu $0,000<0,05$ yang artinya $\mathrm{H}_{0}$ ditolak artinya terdapat perbedaan skor nilai rata-rata kemampuan berpikir kritis siswa antara pre-test dan post-test pada kelas eksperimen. Rata-rata nilai post-test pada kelas eksperimen yaitu 88,12 dan rata-rata nilai pre-test pada kelas eksperimen yaitu 75,92. Selain itu, dilihat pada kriteria penilaian koefiensi $t_{\text {hit }}$ lebih besar dari nilai koefiensi $t_{\text {tab. }}$ Adapun hasil yang diperoleh adalah $t_{\text {hit }}=15,060$ dikonsultasikan pada $t_{\text {tab }}=2,060$ (taraf signifikansi 5\% dan $\mathrm{df}=25$ ), sehingga dapat dikatakan bahwa $t_{h i t}>t_{t a b}$ atau 15,060 $>2,060$ yang artinya terdapat perbedaan skor nilai rata-rata kemampuan berpikir kritis siswa antara pre-test dan post-test pada kelas eksperimen. Dengan demikian dapat disimpulkan bahwa skor nilai kemampuan berpikir kritis siswa sebelum menggunakan media sains flipbook berbeda dengan skor nilai kemampuan berpikir siswa setelah menggunakan media sains flipbook pada kelas eksperimen.

\section{Uji Efektivitas Perbandingan Nilai Post-Test Kelas Eksperimen dengan Kelas Kontrol}

Pada uji efektivitas perbandingan nilai post-test antara kelas ekperimen dengan kelas kontrol ini menggunakan uji Independent Sample T Test. Data yang diujikan adalah nilai post-test pada kelas eksperimen dengan nilai post-test pada kelas kontrol. Uji-t dapat dilakukan setelah data diketahui berdistribusi normal dan homogen, sehingga perlu dilakukan perhitungan uji normalitas dan uji homogenitas terlebih dahulu. Hasil perhitungan uji normalitas dan uji homogenitas dengan menggunakan program SPSS dapat dilihat pada tabel 7 dan 8.

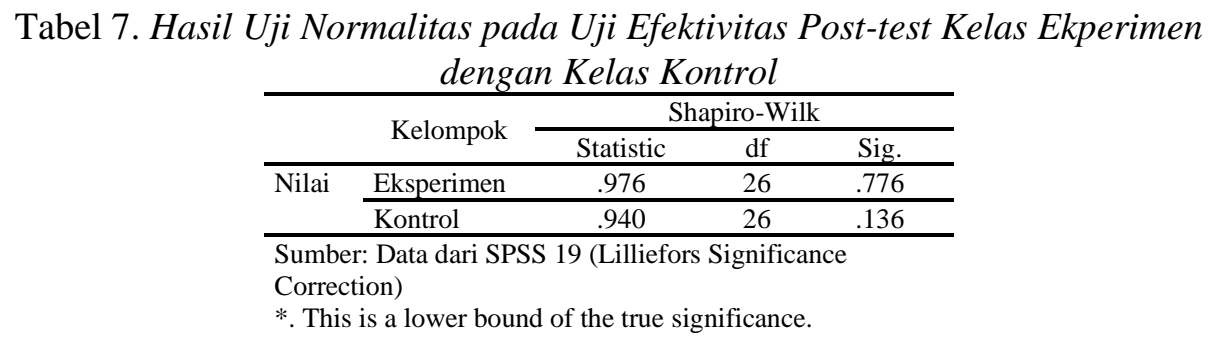

Berdasarkan data tabel 7 perhitungan uji normalitas di atas menunjukkan bahwa nilai sig $0,776>0,05$ untuk nilai post-test kelas eksperimen dan nilai sig $0,136>0,05$ untuk nilai post-test kelas kontrol, maka dapat dikatakan nilai post-test kelas eksperimen dan kelas kontrol adalah data yang berdistribusi normal. 
Jurnal Penelitian Ilmu Pendidikan, 14 (1), 2021 - 17

Aprilia

Tabel 8. Hasil Uji Homogenitas pada Uji Efektivitas Post-test Kelas Ekperimen dengan Kelas Kontrol

\begin{tabular}{cccc}
\hline Levene Statistic & df1 & df2 & Sig. \\
\hline .027 & 1 & 50 & .871 \\
\hline Sumber: Data dari SPSS 19 &
\end{tabular}

Tabel di atas menunjukkan data perhitungan uji homogenitas, diperoleh nilai sig 0,871>0,05 sehingga data nilai post-test kelas eksperimen dan kelas kontrol dapat dikatakan homogen.

Data tabel 8 dikatakan berdistribusi normal dan homogen, maka selanjutnya data nilai posttest kelas eksperimen dan kelas kontrol akan dilakukan perhitungan uji-t atau uji hipotesis. Hasil uji hipotesis dengan menggunakan Independent Sample T Test dapat dilihat pada tabel 9.

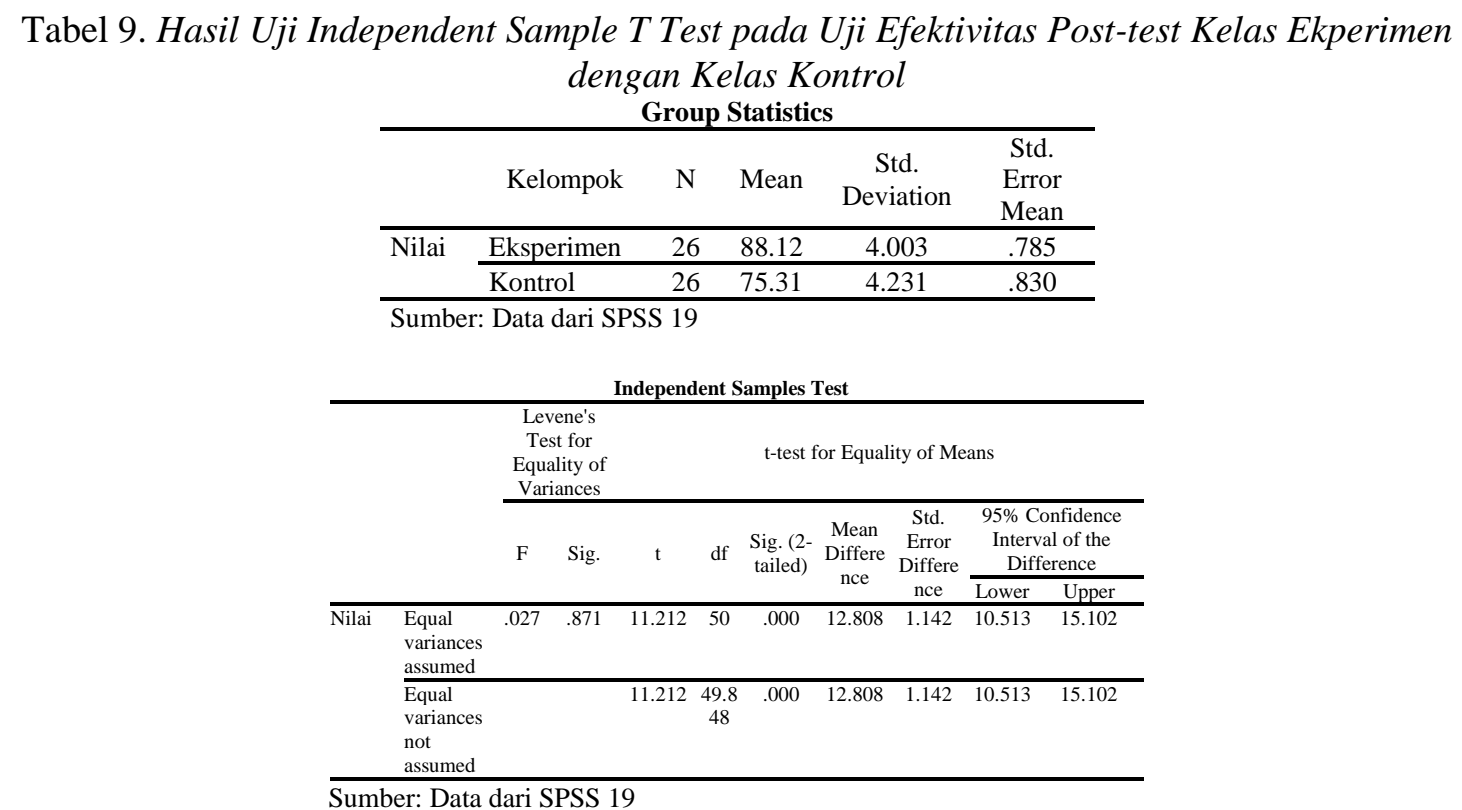

Berdasarkan data tabel di atas hasil uji independent sample t-test menunjukkan bahwa nilai propabilitas atau sig. (2-tailed) yaitu $0,000<0,05$ yang artinya $\mathrm{H}_{0}$ ditolak atau terdapat perbedaan nilai kemampuan berpikir kritis siswa antara kelas kontrol dengan kelas eksperimen. Adapun rata-rata nilai post-test pada kelas eksperimen yaitu 88,12 dan rata-rata nilai post-test pada kelas kontrol yaitu 75,31. Selisih perbedaan rata-ratanya 12,808 dengan perbedaan kisaran antara 10,513 sampai 15,102.

Dilihat pada kriteria penilaian koefiensi $\mathrm{t}_{\text {hit }}$ lebih besar dari nilai koefiensi $\mathrm{t}_{\text {tab }}$ maka $\mathrm{H}_{0}$ ditolak. Adapun hasil yang diperoleh adalah $\mathrm{t}_{\mathrm{hit}}=11,212$ dikonsultasikan pada $\mathrm{t}_{\mathrm{tab}}=2,009$ (taraf signifikansi $5 \%$ dan $\mathrm{df}=50$ ), sehingga dapat dikatakan bahwa $\mathrm{t}_{\text {hit }}>\mathrm{t}_{\text {tab }}$ atau 11,212 $>2,009$ yang artinya ada perbedaan nilai kemampuan berpikir kritis siswa pada kelas eksperimen yang menggunakan media sains flipbook berbasis kontekstual dengan kelas kontrol yang menggunakan media buku cetak atau buku paket IPA.

Gambar 1, menunjukkan bahwa terdapat perbedaan skor rata-rata antara nilai post-test kelas yang menggunakan media sains flipbook dengan nilai post-test kelas yang menggunakan media buku cetak IPA. Dimana skor rata-rata post-test kelas yang menggunakan media sains flipbook yaitu 88,12 lebih tinggi dari skor rata-rata post-test kelas yang menggunakan media buku cetak IPA yaitu 75,31. Dengan demikian dapat disimpulkan bahwa terjadi keefektifan dalam penggunaan media flipbook berbasis kontekstual dalam pembelajaran IPA di kelas V SD Negeri Surakarta. 


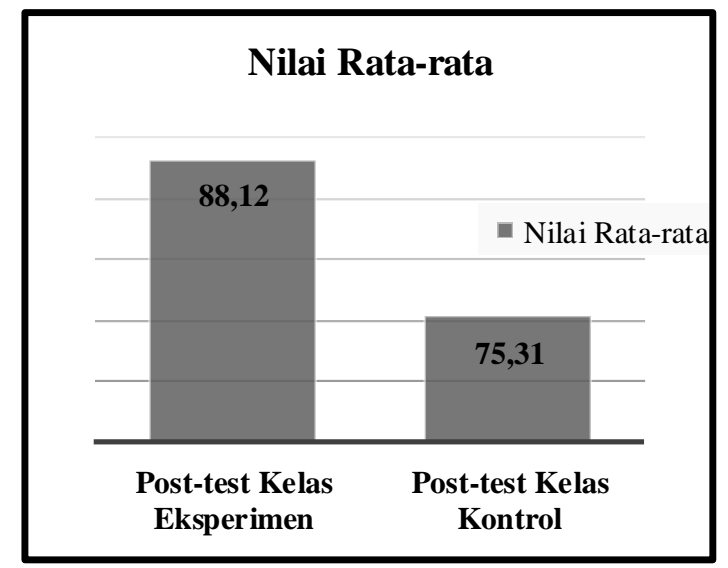

Gambar 1. Diagram nilai rata-rata post-test kelas ekperimen dan kontrol

\section{Pembahasan}

Uji efektivitas media sains flipbook dimulai dengan melakukan uji kesetaraan tersebih dahulu. Hasil uji kesetaraan diperoleh nilai sig sebesar 0,432>0,05 artinya $\mathrm{H}_{0}$ diterima. Hal ini menunjukkan bahwa kemampuan awal siswa kelas eksperimen sama dengan kemampuan awal siswa kelas kontrol, sehingga kedua kelas tersebut dapat digunakan untuk uji efektivitas media sains flipbook berbasis kontekstual.

Tahap selanjutnya baru melakukan uji independent sample t-test untuk mengetahui tingkat keefektifan media setelah diimplementasikan pada kelas ekperimen, yang nantinya dibandingkan dengan kelas kontrol yang hanya menggunakan media buku cetak biasa. Hasil signifikansi yang diperoleh yaitu $0,000<0,05$ yang artinya $\mathrm{H}_{0}$ ditolak. Adapun rata-rata nilai post-test pada kelas eksperimen yaitu 88,12 dan rata-rata nilai post-test pada kelas kontrol yaitu 75,31. Dilihat pada kriteria penilaian koefiensi $t_{\text {hit }}$ lebih besar dari nilai koefiensi $\mathrm{t}_{\text {tab }}$ maka $\mathrm{H}_{0}$ ditolak. Hasil yang diperoleh adalah $t_{\text {hit }}=11,212$ dikonsultasikan pada $t_{\text {tab }}=2,009$, sehingga dapat dikatakan bahwa $t_{\text {hit }}>t_{\text {tab }}$ atau $11,212>2,009$ yang artinya ada perbedaan nilai kemampuan berpikir kritis siswa pada kelas eksperimen yang menggunakan media sains flipbook berbasis kontekstual dengan kelas kontrol yang menggunakan media buku paket IPA.

Berdasarkan data yang telah diuraikan dapat disimpulkan bahwa media sains flipbook berbasis kontekstual dapat meningkatkan kemampuan berpikir kritis siswa kelas V SD dalam pembelajaran IPA. Hal ini membuktikan bahwa media pembelajaran yang berbasis kontesktual akan mudah menumbuhkan pemikiran-pemikiran yang kritis terhadap konsep atau materi yang disajikan (Johnson, 2006). Sependapat dengan Johnson, menyebutkan bahwa model pembelajaran yang berbasis masalah kontekstual yang ada disekitar lingkungan siswa dapat meningkatkan kemampuan berpikir kritis siswa (Asyari et al., 2016; Shofan, SA'dijah \& Slamet, 2012). Selain itu diperkuat juga oleh teorinya yang menyatakan desain template dan pengaturan fitur seperti warna latar belakang dan gambar, tombol kontrol, navigasi bar, dan halaman buku untuk menampilkan flipbook menjadi lebih interaktif dan menarik perhatian siswa sehingga pembelajaran akan berjalan dengan efektif (Kucirkova, 2017; Sugianto, Abdullah, Elvyanti \& Muladi, 2017).

Penggunaan media sains flipbook berbasis kontekstual layak dan efektif digunakan dalam proses pembelajaran IPA di sekolah dasar dan dapat meningkatkan kemampuan berpikir kritis siswa. Hal ini sesuai dengan pendapat (Seamolec, 2013) yang menjelaskan bahwa fungsi dari e-book dalam proses pembelajaran yaitu sebagai media yang dapat meningkatkan produktivitas belajar dan sebagai alat bantu guru dalam mengefektifkan dan mengefensienkan waktu pembelajaran. Sependapat dengan hal tersebut, Rasiman \& Agnita dalam penelitiannya menyatakan media pembelajaran e-comic berbasis flipbook efektif untuk meningkatkan kemampuan berpikir kritis siswa SMP dan menumbuhkan nilai karakter seperti disiplin, kerjasama, kejujuran, kepercayaan diri dan ketekunan (Rasiman \& Pramasdyahsari, 2014). 
Generasi milenial abad ke-21 ini, setiap orang pasti sudah mengenal dan memiliki perangkat yang namanya komputer atau laptop. Tidak hanya di kalangan orang dewasa, anak-anak usia generasi $\mathrm{Z}$ pun telah mahir dalam mengoperasikan komputer atau laptop. Penggunaan teknologi tidak hanya untuk bermain, akan tetapi bisa juga dimanfaatkan dalam kegiatan belajar sambil bermain (CalvoPorral \& Pesqueira-Sanchez, 2019). Berdasarkan survei lapangan yang dilakukan pada penelitian ini menunjukkan bahwa hampir semua siswa kelas V SDN Cemara Dua, SDN Mangkubumen Lor No 15 dan SDN Mangkubumen Kidul No. 16 sudah bisa mengoperasikan komputer atau laptop. Bahkan mayoritas siswa telah memiliki fasilitas komputer atau laptop di rumah masing-masing. Hal ini sejalan dengan penelitian yang dilakukan oleh Bagdasarov, Luo \& Yu (2017) menyebutkan media pembelajaran berbasis digital yang diakses melalui laptop atau tablet dapat berkontribusi terhadap kemampuan berpikir kritis siswa.

Salah satu keuntungannya apabila siswa telah memiliki dasar-dasar kemampuan dalam mengoperasikan komputer atau laptop, siswa dapat menggunakan media sains flipbook berbasis kontekstual ini secara mandiri di sekolah maupun di rumah namun harus tetap dibawah pengawasan guru dan orang tua. Hal ini dikarena penggunaan media sains flipbook mudah dioperasikan dan didalamnya terdapat petunjuk cara menggunakan flipbook. Hal serupa pernah dilakukan oleh Ghofur dan Kustijono dalam penelitiannya, yang menyebutkan bahwa kepraktisan media ebook berbasis flash kvisoft flipbook dapat operasikan secara lancar dan mandiri oleh siswa karena terdapat petunjuk pengoperasian $e$-book (Ghofur \& Kustijono, 2015). Selain itu, siswa dapat beradaptasi $e$-book, asalkan e-book yang digunakan harus mudah diakses, terdapat petunjuk penggunaan tombol navigasi dan mudah untuk dibaca (Cummings, Larrivee \& Vega, 2015; Sun \& Jiang, 2015).

Dalam media sains flipbook berbasis kontekstual memuat berbagai konten media baik media visual, audio, maupun media audiovisual seperti video pembelajaran, sehingga media sains flipbook tergolong dalam jenis multimedia. Fungsi buku multimedia dalam pembelajaran harus mampu memberikan kesempatan pada siswa untuk mengontrol laju kecepatan belajar dan membaca secara mandiri (Daryanto, 2010; Reinking \& Watkins, 2000). Selain itu, dalam media sains flipbook juga terdapat kegiatan-kegiatan diskusi yang memicu siswa untuk berkerjasama dan berani untuk mengungkapkan pendapatnya, sehingga kemampuan siswa dalam berpikir akan meningkat. Mengembangkan pemikiran kritis menuntut latihan menemukan pola, menyusun penjelasan, membuat hipotesis, melakukan generalisasi, dan mengemas temuan bukti dengan matriks lalu mengkomunikasikan informasi (Wulandari, 2019). Sependapat dengan penelitian di atas, Beckmann \& Weber dalam penelitiannya menjelaskan bahwa penggunaan forum diskusi dalam suatu pembelajaran yang menggunakan media berbasis virtual atau digital dapat memperbaiki pemikiran kritis siswa (Beckmann \& Weber, 2016).

Pendapat lain mengemukakan bahwa modul virtual berupa multimedia flipbook dasar teknik digital dapat membuat materi pembelajaran menjadi sangat mudah dipahami oleh peserta didik dan dapat meningkatkan motivasi, minat, dan aktivitas belajar, serta kecepatan membaca peserta didik ketika menggunakan buku digital (Hayati, Budi \& Handoko, 2015; Huang \& Liang, 2015; Kucirkova, 2017). Dengan demikian hasil penelitian ini menunjukkan bahwa media sains flipbook berbasis kontekstual efektif dalam meningkatkan kemampuan berpikir kritis siswa kelas V sekolah dasar. Oleh sebab itu, guru dan sekolah harus mampu memfasilitasi siswa dalam menggunakan media pembelajaran flipbook berbasis kontekstual untuk menunjang kemampuan berpikir kritis siswa di pembelajaran sains sekolah dasar.

Penelitian ini telah dilaksanakan secara maksimal sesuai dengan prosedur penelitian eksperimen, sehingga media sains flipbook berbasis kontekstual efektif dapat mengingkatkan kemampuan berpikir kritis siswa kelas V SD Negeri Surakarta. Akan tetapi dalam pelaksanaannya masih terdapat beberapa keterbatasan. Pertama, muatan materi yang digunakan dalam media sains flipbook masih terbatas pada mata pelajaran IPA Kelas V semester 2 pada KD 5.1 (Gaya) dan KD 5.2 (Pesawat Sederhana). Kedua, media sains flipbook hanya dapat dioperasikan melalui PC atau laptop, sehingga penggunaan media sains flipbook berbasis kontekstual untuk meningkatkan kemampuan berpikir kritis ini sangat membutuhkan sarana prasarana atau fasilitas sekolah yang memadai. 


\section{PENUTUP}

Hasil uji efektivitas media sains flipbook berbasis kontekstual menunjukkan bahwa nilai ratarata hasil belajar siswa yang menggunakan media sains flipbook berbasis kontekstual yaitu 88,12. Nilai rata-rata tersebut lebih tinggi dibandingkan dengan kelas yang menggunakan buku paket IPA, yaitu 75,31. Kemudian dilihat dari hasil uji independent sample t-test diperoleh signifikansi $0,000<$ 0,05 artinya $\mathrm{H}_{0}$ ditolak menunjukkan bahwa ada perbedaan nilai kemampuan berpikir kritis siswa pada kelas eksperimen yang menggunakan media sains flipbook berbasis kontekstual dengan kelas kontrol yang menggunakan media buku cetak/paket IPA.

Media sains flipbook yang digunakan pada kelas ekperimen lebih baik dari pada kelas kontrol yang hanya menggunakan media buku cetak/paket IPA. Selain itu, dari segi efektifitas kemampuan berpikir kritis siswa menunjukkan bahwa skor nilai kemampuan berpikir kritis siswa pada kelas ekperimen yang menggunakan media sains flipbook lebih tinggi dari pada skor nilai kemampuan berpikir kritis siswa kelas kontrol yang hanya menggunakan media buku paket IPA. Dengan demikian dapat disimpulkan bahwa media sains flipbook berbasis kontekstual efektif dapat meningkatkan kemampuan berpikir kritis siswa pada mata pelajaran IPA kelas V SD Semester 2 pada materi Gaya dan Pesawat Sederhana.

Penggunaan media sains flipbook dalam meningkatkan kemampuan berpikir kritis siswa memiliki dampak positif bagi guru maupun siswa. Guru dapat mempermudah dalam menyampaikan materi dalam mata pelajaran IPA dengan menggunakan media sains flipbook. Sedangkan bagi siswa, siswa menjadi lebih mudah untuk memahami materi yang diajarkan guru pada mata pelajaran IPA. Selain itu, dengan adanya media sains flipbook yang berisi berbagai konten interaktif, menyenangkan dan berbasis kontektual sesuai dengan kehidupan sehari-hari siswa, seperti video pembelajaran, teks disertai contoh penerapannya dalam bentuk gambar konkret, kuis, dan berbagai aktivitas kegiatan lainnya, sangat efektif untuk melatih kemandirian belajar siswa dan kemampuan berpikir kritis siswa sekolah dasar.

\section{UCAPAN TERIMA KASIH}

Penulis mengucapkan terima kasih khususnya kepada Prof. Dr. Sunardi, M.Sc. dan Dr. Djono, M.Pd. yang telah memberikan masukan dan arahan sehingga penelitian ini dapat selesai tepat waktu.

\section{DAFTAR PUSTAKA}

Andrian, Y., \& Rusman, R. (2019). Implementasi pembelajaran abad 21 dalam kurikulum 2013. Jurnal Penelitian Ilmu Pendidikan. https://doi.org/10.21831/jpipfip.v12i1.20116.

Aqib, Z. (2014). Model-model, media, dan strategi pembelajaran kontekstual (inovatif). Bandung: Yrama Wijaya.

Asyari, M., Al Muhdhar, M. H. I., Susilo, H., \& Ibrohim, I. (2016). Improving critical thinking skills through the integration of problem based learning and group investigation. International Journal for Lesson and Learning Studies. https://doi.org/10.1108/JJLLS-10-2014-0042.

Bagdasarov, Z., Luo, Y., \& Wu, W. (2017). The Influence of tablet-based technology on the development of communication and critical thinking skills: An interdisciplinary study. Journal of Research on Technology in Education, 49(1-2), 55-72. https://doi.org/10.1080/15391523.2017.1293576.

Beckmann, J., \& Weber, P. (2016). Cognitive presence in virtual collaborative learning: Assessing and improving critical thinking in online discussion forums. Interactive Technology and Smart Education. https://doi.org/10.1108/ITSE-12-2015-0034.

Brownie, M., \& Keeley, S. (2015). Pemikiran kritis: Panduan untuk mengajukan dan menjawab pertanyaan kritis. Jakarta: PT. Indeks.

Calvo-Porral, C., \& Pesqueira-Sanchez, R. (2019). Generational differences in technology behaviour: comparing millennials and generation X. Kybernetes, 49(11), 2755-2772. https://doi.org/10.1108/K-09-2019-0598.

Cummings, L. A., Larrivee, A., \& Vega, L. (2015). Comparing electronic vs print book preferences 
between students in the social sciences, the arts and stem. Library Hi Tech News. https://doi.org/10.1108/lhtn-10-2014-0088.

Daryanto. (2010). Media pembelajaran. Yogyakarta: Gava Media.

Ghofur, A., \& Kustijono, R. (2015). Pengembangan e-book berbasis flash kvisoft flipbook pada materi kinematika gerak lurus sebagai sarana belajar siswa sma kelas X. Jurnal Inovasi Pendidikan Fisika (JIPF).

Hayati, S., Budi, A. S., \& Handoko, E. (2015). Pengembangan media pembelajaran flipbook fisika untuk meningkatkan hasil belajar peserta didik. Prosiding Seminar Nasional Fisika (e-Jurnal) SNF2015.

Huang, Y. M., \& Liang, T. H. (2015). A technique for tracking the reading rate to identify the e-book reading behaviors and comprehension outcomes of elementary school students. British Journal of Educational Technology, 46(4), 864-876. https://doi.org/10.1111/bjet.12182.

Johnson, E. (2006). Contextual teaching and learning (menjadikan kegiatan belajar mengasyikan dan bermakna) terjemahan ibnu setiawan. In The SAGE Encyclopedia of Online Education. https://doi.org/10.4135/9781483318332.n86.

Kucirkova, N. (2017). An integrative framework for studying, designing and conceptualising interactivity in children's digital books. British Educational Research Journal, 43(6), 11681185. https://doi.org/10.1002/berj.3317.

OECD. (2016). PISA 2015 results (volume I): Excellence and equity in education. In Pisa. https://doi.org/10.1787/9789264266490-en.

Parlin, I. D. P. L., Iswanto, B. H., \& Budi, A. S. (2015). Pengembangan media pembelajaran berbasis kvisoft untuk meningkatkan pemahaman konsep peserta didik pada materi medan magnet. Prosiding Seminar Nasional Fisika (E-Journal) SNF2015, 135-140. http://journal.unj.ac.id/unj/index.php/prosidingsnf/article/view/4685.

Rasiman, \& Pramasdyahsari, A. S. (2014). Development of mathematics learning media e-comic based on flip book maker to increase the critical thinking skill and character of junior high school students. International Journal of Education and Research, 11(2), 535-544.

Reinking, D., \& Watkins, J. (2000). A formative experiment investigating the use of multimedia book reviews to increase elementary students' independent reading. Reading Research Quarterly, 35(3), 384-419. https://doi.org/10.1598/rrq.35.3.4.

Samatowa, U. (2011). Pembelajaran ipa di sd. Jakarta: PT Indeks.

Seamolec. (2013). Simulasi digital jilid 2: Buku siswa smk/mak kelas x. Jakarta: Kementerian Pendidikan dan Kebudayaan RI.

Shofan, M., Sa'dijah, C., \& Slamet. (2012). Pengembangan modul pembelajaran bilangan bulat dengan pendekatan kontekstual untuk siswa kelas iv sd/mi. Jurnal Online UM.

Sugianto, D., Abdullah, A. G., Elvyanti, S., \& Muladi, Y. (2017). Modul virtual: Multimedia flipbook dasar teknik digital. Innovation of Vocational Technology Education. https://doi.org/10.17509/invotec.v9i2.4860.

Sukmadinata, N. S. (2012). Metode penelitian pendidikan. Bandung: PT Remaja Rosdakarya.

Sun, Z., \& Jiang, Y. (2015). How the young generation uses digital textbooks via mobile learning terminals: Measurement of elementary school students in China. British Journal of Educational Technology, 46(5), 961-964. https://doi.org/10.1111/bjet.12299.

Suryabrata, S. (2014). Metode penelitian. Jakarta: PT Raja Gravindo Persada.

Winkel, W. S. (2007). Psikologi pendidikan. Yogyakarta: Media Abadi.

Wulandari, R. (2019). The effect of integrative learning model and critical thinking ability toward students' historical learning outcome in sma negeri 13 Bekasi. Jurnal Penelitian Ilmu Pendidikan. https://doi.org/10.21831/jpipfip.v12i2.23473. 